\title{
PENINGKATAN SELF-EFFICACY MAHASISWA MELALUI PROBLEM BASED LEARNING (PBL) PADA MATA KULIAH PROGRAM LINIER
}

\author{
Dina Octaria ${ }^{1}$, Eka Fitri Puspa Sari² \\ ${ }^{1,2}$ Universitas PGRI Palembang \\ dinaoctaria@univpgri-palembang.ac.id
}

\begin{abstract}
Abstrak
Penelitian ini bertujuan untuk mengkaji peningkatan self-efficacy mahasiswa pada mata kuliah program linier setelah mendapat model pembelajaran problem based learning (PBL) dan pembelajaran konvensional ditinjau dari keseluruhan maupun KAM (tinggi, sedang, dan rendah).Subyek dalam penelitian ini adalah mahasiswa semester IV program studi pendidikan matematika universitas PGRI Palembang tahun akademik 2016/2017 yang mengontrak mata kuliah program linier yang berjumlah 62 orang.Penelitian ini menggunakan metode kuasi-eksperimen dengan desain kelompok pretes dan postes tak ekuivalen. Instrumen yang digunakan dalam penelitian ini yaitu tes KAM dan skala selfefficacy, analisis data menggunakan uji-t. Hasil penelitian menunjukkan bahwa peningkatan self-efficacy mahasiswa pada mata kuliah program linier yang mendapat PBL lebih baik daripada mahasiswa yang mendapat pembelajaran konvensional ditinjau dari keseluruhan maupun KAM (sedang, rendah) meskipun dengan nilai gain berada pada kategori rendah, sedangkan untuk KAM tinggi berada pada kategori sedang.
\end{abstract}

Kata kunci: Problem Based Learning (PBL), Self-Efficacy

\begin{abstract}
This study aims to examine the improvement of students' self-efficacy in the linear program after learning model of learning problem based learning (PBL) and conventional learning in terms of overall and KAM (high, medium and low). The subjects in this study are students of the fourth semester of the mathematics education program of PGRI Palembang university academic year 2016/2017 which contracted the linier program which amounted to 62 people. This study used quasi-experimental method with pretest group design and non-equivalent postes. The instruments used in this research are KAM test and self-efficacy scale, data analysis using t-test. The result of the research shows that the increase of student self-efficacy in the linear programming courses that get the PBL is better than the students who get conventional learning in terms of overall or KAM (medium, low) even though the value of gain is in low category, while for high KAM are in the medium category.
\end{abstract}

Keywords: Problem Based Learning (PBL), Self-Efficacy

\section{PENDAHULUAN}

Program linier merupakan mata kuliah wajib tempuh bagi mahasiswa di Program Studi Pendidikan Matematika. Mata kuliah prasyarat dalam mempelajari program linier adalah penguasaan terhadap mata kuliah aljabar linear. Sama halnya dengan pencarian solusi pada kasus yang dapat diselesaikan menggunakan aljabar linear, pada pencarian solusi masalah 
program linier harus diterjemahkan ke dalam simbol-simbol untuk menunjang proses analisis. Secara umum tahapan dalam kegiatan analisis simpleks pada program linier terdiri dari dua bagian, yaitu tahap pra-analisis dan tahap analisis. Sitorus (Kartono, dkk : 2007) menjelaskan tujuh tahapan dalam tahap analisis penyelesaian program linier menggunakan metode simpleks. Pada tahap ketujuh proses penyelesaian dapat dikatakan selesai apabila masalah pada program linier tersebut telah mencapai titik optimum. Namun apabila pada tahap ketujuh tersebut belum mencapai titik optimum, maka proses penyelesaian akan kembali kepada prosedur tahap keempat, dan hal ini dilakukan terus menerus hingga memperoleh titik optimum.

Dengan mempelajari program linier, diharapkan mahasiswa dapat membentuk kemampuan analisis, sistematis, dan mempunyai sifat objektif, tekun, serta disiplin dalam memecahkan suatu permasalahan dalam bidang matematika maupun dalam bidang lain. Hal ini senada dengan pendapat Kholidi dan Saragih (2011) yang menyatakan bahwa salah satu indikator pembelajaran yang berkualitas baik adalah tingginya tingkat pengetahuan serta adanya interaksi mahasiswa terhadap materi yang diajarkan pada kehidupan nyata. Interaksi belajar mengajar merupakan suatu kegiatan yang bersifat interaktif dari berbagai komponen untuk mewujudkan tercapainya tujuan pembelajaran yang telah ditetapkan dalam perencanaan pembelajaran.

Fakta di lapangan belum sesuai dengan tujuan pembelajaran. Berdasarkan pengalaman peneliti selama mengajar diperoleh bahwa kesulitan mahasiswa dalam menyelesaikan persoalan dalam program linier disebabkan rasa ketidakpercayaan diri mahasiswa dalam proses perhitungan pada tiap-tiap tahapan hingga memperoleh nilai (titik) optimum. Ketidakpercayaan diri mahasiswa tersebut menyebabkan mahasiswa jenuh dan mudah putus asa dalam menyelesaikan persoalan program linier.

Menurut Bandura (Islahul dan Utiya, 2015) siswa lebih proaktif terhadap reaksi yang datang dari dalam diri sendiri daripada reaksi yang datang dari luar. Salah satu dari kepercayaan diri tersebut adalah penilaian siswa tersebut akan kemampuan dirinya untuk berhasil dalam melakukan suatu tugas tertentu atau self-efficacy, sehingga keberhasilan siswa dalam belajar dipengaruhi kepercayaan diri siswa tersebut terhadap dirinya sendiri. Hal ini diperkuat oleh Mahardikawati (2011) dalam penelitiannya menyimpulkan bahwa semakin tinggi self-efficacy maka semakin tinggi prestasi belajar yang dicapai siswa dan semakin rendah self-efficacy maka semakin rendah pula prestasi belajar siswa.

The Self-Esteem Seekers Anonymous (SEA's) program (Sulthon, 2014) menyebutkan bahwa gejala mahasiswa yang memiliki self-efficacy rendah, tampak kurang percaya diri, 
meragukan kemampuan akademisnya, tidak berusaha mencapai nilai tinggi di bidang akademik antara lain: (1) meragukan kemampuannya (self-doubt); (2) malu dan menghindari tugas-tugas sulit; (3) kurang memiliki aspirasi, komitmennya rendah dalam mencapai tujuan; (4) menghindar, melihat tugas-tugas sebagai rintangan, dan merasa rugi menyelesaikannya; (5) usaha kurang optimal dan cepat menganggap sulit; (6) lambat memperbaiki self-efficacy apabila mengalami kegagalan; (7) merasa tidak memiliki cukup kemampuan dan bersikap defensif serta tidak belajar dari banyak kegagalan yang dialaminya; (8) mudah menyerah, malas, stres, dan depresi; (9) meragukan kemampuan ini mendorong mereka percaya pada hal-hal yang tidak rasional dan yang tidak mendasar pada kenyataan; (10) cenderung takut, tidak aman dan manipulatif; (11) cepat menyerah, merasa tidak akan pernah berhasil; dan (12) meyakini seakan-akan segalanya "telah gagal". Pikiran tidak rasional ini berkembang menjadi pikiran negatif (self-scripts) yang terus dipelihara oleh orang yang rendah diri.

Menurut Bandura (1994) Persepsi Self-efficacy dapat dibentuk dengan menginterpretasi informasi dari empat sumber yaitu: (1) Enactive Mastery Experience (Pengalaman otentik), pengalaman akan kesuksesan adalah sumber yang paling besar pengaruhnya terhadap self efficacy individu karena didasarkan pada pengalaman otentik; (2) Vicarious Experience (Pengalaman orang lain), self efficacy juga dipengaruhi pengalaman orang lain. Pengamatan individu akan keberhasilan individu lain dalam bidang tertentu akan meningkatkan selfefficacy individu tersebut pada bidang yang sama; (3) Verbal Persuasion, seseorang yang diyakini secara verbal bahwa ia memiliki kemampuan untuk menguasai tugas yang diberikan kemungkinan besar akan mengerahkan usaha yang lebih besar dan akan mempertahankan usahanya daripada menyimpan keraguan dan memikirkan kekurangan dirinya pada saat kesulitan muncul; (4) Physiological and affective states, dalam menilai kemampuannya orang-orang dapat mengandalkan keadaan fisiologis dan emosi yang dialaminya, selain keadaan fisiologis mood juga mempengaruhi self efficacy seseorang.

Menurut Bandura (1997) terdapat hubungan antara pengalaman (mastery experience) dengan tindakan, seseorang akan membuat perubahan dalam self-efficacy beliefs yang dimilikinya. Hal tersebut sangat tergantung pada faktor-faktor berikut: (1) anggapan seseorang pada kemampuan, (2) tingkatan tugas yang dirasakan sulit, (3) upaya yang dilakukan untuk mencapai kemampuan, (4) jumlah bantuan yang diterima oleh seseorang, (5) keadaan dan kondisi seseorang dalam melakukan tindakan-tindakan mereka, (6) waktu ketika seseorang berhasil dan gagal, (7) metode seseorang dalam memanipulasi dan mengatur enactive mastery experience melalui proses kognitif. 
Salah satu usaha untuk meningkatkan kepercayaan diri mahasiswa melalui proses kognitif yaitu dengan memilih strategi pembelajaran yang tepat dan inovatif dalam pembelajaran matematika di perguruan tinggi. Model pembelajaran yang diduga dapat meningkatkan kepercayaan diri mahasiswa salah satunya yaitu PBL. Menurut Dasna \& Sutrisno (2010) PBL adalah suatu model pembelajaran yang melibatkan mahasiswa untuk memecahkan suatu masalah melalui tahap-tahap metode ilmiah, sehingga penerapan PBL diharapkan mampu membuka pemahaman dan pemikiran yang terbuka pada mahasiswa dan juga melatih kepercayaan diri mereka dalam menyelesaikan persoalan dalam program linier.

Menurut Sanjaya (2011) PBL memiliki keunggulan yaitu: (1) PBL merupakan model yang cukup bagus untuk lebih memahami isi pelajaran, (2) pemecahan masalah dapat menantang kemampuan siswa serta memberikan kepuasan untuk menemukan pengetahuan bagi siswa, (3) dapat meningkatkan aktivitas pembelajaran siswa, (4) dapat membantu siswa untuk membentuk pengetahuan mereka untuk memahami masalah dalam kehidupan nyata, (5) dapat membantu siswa untuk mengembangkan pengetahuan barunya dan bertanggung jawab dalam pembelajaran yang mereka lakukan, (6) dapat mendorong untuk melakukan evaluasi sendiri baik hasil maupun proses belajarnya, (7) dapat memperlihatkan kepada siswa bahwa setiap mata pelajaran pada dasarnya cara berfikir dan sesuatu yang harus dimengerti oleh siswa bukan hanya sekedar belajar dari guru atau buku-buku saja, (8) PBL dianggap lebih menyenangkan dan disukai siswa, (9) dapat memberikan kesempatan kepada siswa untuk mengaplikasikan pengetahuan yang mereka miliki dalam dunia nyata.

Hasil penelitian Islahul dan Utiya (2015) menujukkan self-efficacy berhasil dilatihkan dengan model pembelajaran berbasis masalah dengan adanya peningkatan perilaku selfefficacy pada setiap pertemuan terlihat dari nilai $n$-gain yang diperoleh bernilai positif dengan kriteria cukup. Demikian juga penelitian Tarmizi dan Bayat (2012) dengan membandingkan kinerja kelompok PBL dan konvensional menunjukkan adanya perbedaan yang signifikan. Kinerja rata-rata dari kelompok PBL lebih baik dari konvensional. Pusat efektivitas PBL adalah kemampuan siswa untuk bekerja dalam memecahkan masalah, sehingga PBL dapat dirancang untuk memfasilitasi pembelajaran kolaboratif siswa.

Berdasarkan uraian di atas, penelitian ini bertujuan untuk mengkaji peningkatan selfefficacy mahasiswa pada mata kuliah program linier setelah mendapat model pembelajaran problem based learning (PBL) dan pembelajaran konvensional ditinjau dari keseluruhan maupun KAM (tinggi, sedang, dan rendah). 


\section{METODE}

Penelitian ini merupakan penelitian kuasi eksperimen. Desain penelitian yang digunakan adalah desain kelompok kontrol pretes dan postes tak ekivalen (Creswell, 2009). Secara ringkas desain eksperimen tersebut dapat digambarkan sebagai berikut.

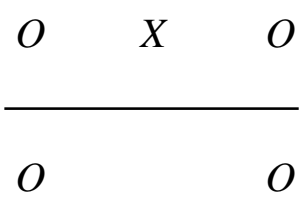

Keterangan:

$O:$ pretes/postes tentang pemecahan masalah

$X$ : Perlakuan berupa problem based learning (PBL)

Populasi dalam penelitian ini adalah mahasiswa Program Studi Pendidikan Matematika Universitas PGRI Palembang, teknik pengambilan sampel yang digunakan adalah purposive sampling. Berdasarkan teknik tersebut diperoleh sampel adalah mahasiswa Program Studi Pendidikan Matematika yang mengikuti perkuliahan Program Linier pada semester genap, Februari - Mei tahun 2017 yaitu kelas 4B sebagai kelas eksperimen sebanyak 30 orang dan kelas 4A sebagai kelas kontrol sebanyak 32 orang.Teknik pengumpulan data menggunakan tes KAM dan Skala Self-efficacy.

\section{Tes KAM}

Tes kemampuan awal mahasiswa bertujuan untuk mengetahui kesetaraan kemampuan mahasiswa pada pembelajaran PBL dan pembelajaran konvensional, selain itu KAM juga digunakan untuk penempatan mahasiswa. TKAM yang digunakan berasal dari soal-soal yang ada dan telah diuji validitas dan reliabilitasnya.

\section{Skala Self-efficacy}

Skala ini digunakan untuk mengukur tingkat kepercayaan diri mahasiswa. Skala ini disusun dan dikembangkan berdasarkan empat aspek SE, yaitu aspek pengalaman otentik, aspek pengalaman dari orang lain, aspek pendekatan sosial/verbal, dan aspek indeks psikologis. Skala yang digunakan ini merupakan modifikasi dari skalaSelf-efficacy yang dikembangkan Somakim (2010), yang terdiri dari 30 item peryataan dengan empat pilihan, yaitu Sangat Setuju (SS), Setuju (S), Tidak Setuju (TS), dan Sangat Tidak Setuju (STS). Pemberian skor setiap pilihan ditentukan secara aposteriori, yaitu berdasarkan distribusi jawaban responden atau dengan kata lain menentukan nilai skala dengan deviasi normal (Azwar, 2009). 
Data yang diperoleh dari hasil pretes dan postes dianalisis untuk mengetahui besarnya peningkatan self-efficacy mahasiswa kelas eksperimen dan kelas kontrol menggunakan rumus gain ternormalisasi (Hake dalam Rohana, 2016) dengan interpretasi kategori n-gain seperti pada Tabel 1.

Tabel 1.Kategori $n$-gain $(g)$

\begin{tabular}{ll}
\hline $\boldsymbol{n}$-gain $(\boldsymbol{g})$ & Interpretasi \\
\hline$g>0,7$ & Tinggi \\
\hline $0,3<g \leq 0,7$ & Sedang \\
\hline$g \leq 0,3$ & Rendah \\
\hline
\end{tabular}

Untuk menguji hipotesis dilakukan pengujian statistik inferensial menggunakan uji t.

\section{HASIL DAN PEMBAHASAN}

\section{Hasil Penelitian}

\section{Deskripsi Data KAM}

Kemampuan awal mahasiswa (KAM) menggambarkan pengetahuan dan keterampilan mahasiswa tentang matematika sebelum dilibatkan sebagai subjek dalam penelitian. Tes KAM selain digunakan untuk mengetahui kesetaraan subjek sampel penelitian, juga digunakan untuk mengelompokkan mahasiswa menurut kemampuan matematis yang dimiliki mahasiswa sebelum proses pembelajaran, data dianalisis secara deskriptif agar dapat diketahui rata-rata, simpangan baku, nilai minimum, dan nilai maksimum untuk setiap kelompok KAM, yaitu tinggi (T), sedang (S), dan rendah (R). Rangkuman hasil analisis data KAM disajikan pada Tabel 2.

Tabel 2. Statistik deskriptif data kemampuan awal mahasiswa

\begin{tabular}{|c|c|c|c|c|c|c|}
\hline \multirow{2}{*}{$\begin{array}{c}\text { Kelompok } \\
\text { KAM }\end{array}$} & \multirow{2}{*}{ Pembelajaran } & \multirow{2}{*}{$N$} & \multicolumn{2}{|c|}{ Skor } & \multirow{2}{*}{ Rerata } & \multirow{2}{*}{$\begin{array}{c}\text { Simpangan } \\
\text { Baku }\end{array}$} \\
\hline & & & Min & Maks & & \\
\hline \multirow{2}{*}{ Tinggi } & PBL & 8 & 8 & 12 & 9,50 & 1,41 \\
\hline & PK & 6 & 8 & 10 & 8,50 & 0,84 \\
\hline \multirow{2}{*}{ Sedang } & PBL & 20 & 5 & 8 & 8,94 & 1,29 \\
\hline & PK & 21 & 5 & 9 & 8,94 & 1,31 \\
\hline \multirow{2}{*}{ Rendah } & PBL & 8 & 3 & 4 & 4,94 & 1,20 \\
\hline & PK & 4 & 2 & 4 & 5,07 & 1,00 \\
\hline \multirow{2}{*}{ Keseluruhan } & PBL & 34 & 3 & 11 & 8,61 & 2,69 \\
\hline & $\mathrm{PK}$ & 30 & 2 & 12 & 9,09 & 2,86 \\
\hline
\end{tabular}

Keterangan: Skor Maksimal Ideal $=15$

Dari tabel 2 menunjukkan bahwa secara keseluruhan maupun dilihat dari kelompok KAM tidak terdapat perbedaan yang signifikan pada kedua pembelajaran, sehingga dapat 
diberikan perlakuan yang berbeda pada setiap kelas sampel. Perlakuan ini bertujuan untuk melihat perbedaan peningkatan kemampuan mahasiswa pada akhir pembelajaran.

Sebelum dilakukan uji statistik, terlebih dahulu dilakukan uji normalitas data dan uji homogenitas varians. Dari hasil perhitungan diperoleh, data normal dan homogen. Selanjutnya dilakukan uji-t. Dari data penelitian, diperoleh uji kesetaraan data KAM berdasarkan keseluruhan maupun pembelajaran dan kelompok KAM (tinggi, sedang, rendah) disajikan pada Tabel 3berikut.

Tabel 3. Uji perbedaan data kemampuan awal mahasiswa

\begin{tabular}{llcc}
\hline \multicolumn{1}{c}{ Kelompok KAM } & Statistik $\boldsymbol{t}$ & Sig & Ho \\
\hline Keseluruhan & $-0,477$ & 0,635 & Diterima \\
\hline Tinggi & $-1,533$ & 0,151 & Diterima \\
\hline Sedang & 0,122 & 0,904 & Diterima \\
\hline Rendah & 0,355 & 0,728 & Diterima \\
\hline
\end{tabular}

$\mathrm{H}_{0}$ : Tidak terdapat perbedaan rerata skor KAM antar kedua kelompok data

Dari Tabel 3 diperoleh nilai probabilitas (sig.) > taraf signifikansi $\alpha=0,05$ sehingga $\mathrm{H}_{0}$ diterima. Hal ini berarti, tidak terdapat perbedaan yang signifikan antara rerata data KAM mahasiswa yang mendapat PBL dan mahasiswa yang mendapat PK ditinjau secara keseluruhan maupun berdasarkan kelompok KAM (tinggi, sedang, rendah).

\section{Deskripsi Data Skala Self-Efficacy}

Dari data penelitian diperoleh rata-rata, simpangan baku, skor pretes, postes, $n$-gain SE berdasarkan pembelajaran, KAM dan secara keseluruhan. Rangkuman hasil analisis data disajikan pada Tabel 4.

Tabel 4. Statistik deskriptif data peningkatan self-efficacy (SE) mahasiswa

\begin{tabular}{|c|c|c|c|c|c|c|c|c|c|c|}
\hline \multirow{2}{*}{$\begin{array}{c}\text { Kelompok } \\
\text { KAM }\end{array}$} & \multicolumn{5}{|c|}{ Pembelajaran PBL } & \multicolumn{5}{|c|}{$\begin{array}{c}\text { Pembelajaran Konvensional } \\
\text { (PK) }\end{array}$} \\
\hline & $N$ & Stat. & Pretes & Postes & $\langle\mathrm{g}\rangle$ & $N$ & Stat. & Pretes & Postes & $\langle\mathrm{g}\rangle$ \\
\hline \multirow{2}{*}{ Keseluruhan } & \multirow{2}{*}{30} & $\bar{x}$ & 61,4 & 72,2 & 0,25 & \multirow{2}{*}{32} & $\bar{x}$ & 64,25 & 70,75 & 0,15 \\
\hline & & $S$ & 6,16 & 7,90 & 0,10 & & $s$ & 6,53 & 6,75 & 0,09 \\
\hline \multirow{2}{*}{ Tinggi } & \multirow{2}{*}{8} & $\bar{x}$ & 66,38 & 78,75 & 0,32 & \multirow{2}{*}{6} & $\overline{\bar{x}}$ & 64,67 & 74,83 & 0,25 \\
\hline & & $S$ & 4,93 & 7,55 & 0,12 & & $s$ & 4,27 & 5,84 & 0,09 \\
\hline \multirow{2}{*}{ Sedang } & \multirow{2}{*}{13} & $\bar{x}$ & 66,69 & 72,07 & 0,23 & \multirow{2}{*}{18} & $\bar{x}$ & 66,11 & 72,22 & 0,15 \\
\hline & & $S$ & 21,19 & 6,94 & 0,09 & & $s$ & 6,39 & 5,06 & 0,07 \\
\hline \multirow{2}{*}{ Rendah } & \multirow{2}{*}{9} & $\bar{x}$ & 56 & 66,55 & 0,21 & & $\bar{x}$ & 59,75 & 64,38 & 0,10 \\
\hline & & $S$ & 4 & 5,03 & 0,09 & & $s$ & 6,67 & 7,00 & 0,06 \\
\hline
\end{tabular}

Skor Maksimal Ideal $=106$ 
Pada Tabel 4. memberikan gambaran umum bahwa kualitas peningkatan kemampuan self-efficacy mahasiswa berdasarkan keseluruhan maupun kelompok KAM yang memperoleh PBL lebih baik dibandingkan dengan mahasiswa yang memperoleh PK. Hal ini ditunjukkan dengan perolehan skor rerata n-gain mahasiswa secara keseluruhan dari kelompok PBL sebesar 0,25 lebih besar dibandingkan dengan perolehan skor rerata n-gain mahasiswa dari kelompok PK hanya sebesar 0,15. Terlihat juga nilai gain untuk self-efficacy mahasiswa pada mata kuliah program linier pada pembelajaran PBL berada pada kategori rendah, sedangkan untuk KAM tinggi nilai $n$-gain self-efficacy mahasiswa berada pada kategori sedang.

\section{Analisis Data Peningkatan Self-efficacy Mahasiswa}

Untuk mengetahui apakah terdapat perbedaan peningkatan self-efficacy mahasiswa pada mata kuliah program linier yang mendapatkan pembelajaran PBL dan mahasiswa yang mendapatkan pembelajaran konvensional, baik ditinjau secara keseluruhan maupun berdasarkan pembelajaran dan KAM diajukan hipotesis berikut: (1) Secara keseluruhan, mahasiswa yang mendapat pembelajaran PBL memperoleh peningkatan self-efficacy lebih baik daripada mahasiswa yang mendapat pembelajaran konvensional; (2) Mahasiswa yang mendapat pembelajaran PBL memperoleh peningkatan self-efficacy lebih baik daripada mahasiswa yang mendapat pembelajaran konvensional ditinjau dari KAM tinggi; (3) Mahasiswa yang mendapat pembelajaran PBL memperoleh peningkatan self-efficacy lebih baik daripada mahasiswa yang mendapat pembelajaran konvensional ditinjau dari KAM sedang; (4) Mahasiswa yang mendapat pembelajaran PBL memperoleh peningkatan selfefficacy lebih baik daripada mahasiswa yang mendapat pembelajaran konvensional ditinjau dari KAM rendah. Sebelum melalukan uji statistik yaitu uji-t, terlebih dahulu dilakukan uji prasyarat analisis, yaitu uji normalitas data dan uji homogenitas varians.

Tabel 5. Uji normalitas data peningkatan self-efficacy (SE) mahasiswa

\begin{tabular}{cccccc}
\hline $\begin{array}{c}\text { Kelompok } \\
\text { KAM }\end{array}$ & Pembelajaran & $\boldsymbol{n}$ & K-S & Sig. & Ho \\
\hline \multirow{2}{*}{ Keseluruhan } & PBL & 30 & 0,453 & 0,987 & Diterima \\
\cline { 2 - 6 } & PK & 32 & 0,542 & 0,930 & Diterima \\
\hline \multirow{2}{*}{ Tinggi } & PBL & 8 & 0,350 & 1,000 & Diterima \\
\cline { 2 - 6 } & PK & 6 & 0,625 & 0,830 & Diterima \\
\hline \multirow{2}{*}{ Sedang } & PBL & 13 & 0,535 & 0,937 & Diterima \\
\cline { 2 - 6 } & PK & 18 & 0,741 & 0,642 & Diterima \\
\hline \multirow{2}{*}{ Rendah } & PBL & 9 & 0,413 & 0,996 & Diterima \\
\cline { 2 - 6 } & PK & 8 & 0,360 & 0,999 & Diterima \\
\hline
\end{tabular}


Pada Tabel 5 menunjukkan bahwa secara keseluruhan maupun kelompok KAM (tinggi, sedang, rendah) nilai probabilitas (sig.) data peningkatan Self-Efficacy pada PBL dan PK lebih besar dari 0,05, yang berarti hipotesis nol diterima. Artinya baik secara keseluruhan maupun kelompok KAM (tinggi, sedang, rendah) untuk setiap pembelajaran (PBL dan PK) menunjukkan bahwa sampel berasal dari populasi yang berdistribusi normal.

Setelah dilakukan uji normalitas, selanjutnya dilakukan uji homogenitas. Hasil uji homogenitas data peningkatan Self-Efficacy dapat dilihat pada Tabel 6.

Tabel 6. Hasil uji homogenitas data peningkatan self-efficacy (SE) mahasiswa

\begin{tabular}{cccc}
\hline $\begin{array}{c}\text { Kelompok } \\
\text { KAM }\end{array}$ & $\begin{array}{c}\text { Statistik } \\
\text { Lavene }\end{array}$ & Sig. & Ho \\
\hline Keseluruhan & 0,859 & 0,358 & Diterima \\
\hline Tinggi & 0,049 & 0,828 & Diterima \\
\hline Sedang & 0,595 & 0,447 & Diterima \\
\hline Rendah & 1,765 & 0,204 & Diterima \\
\hline
\end{tabular}

Pada Tabel 6 menunjukkan bahwa secara keseluruhan maupun kelompok KAM (tinggi, sedang, rendah) nilai probabilitas (sig.) data peningkatan Self-Efficacy lebih besar dari 0,05, yang berarti hipotesis nol diterima. Artinya baik secara keseluruhan maupun kelompok KAM (tinggi, sedang, rendah) menunjukkan bahwa kedua kelompok data bervarians homogen. Karena data peningkatan Self-Efficacy yang diperoleh berdistribusi normal dan homogen, maka untuk mengetahui apakah terdapat perbedaan peningkatan Self-Efficacy mahasiswa yang mendapat pembelajaran PBL dengan mahasiswa yang mendapat pembelajaran konvensional selanjutnya dilakukan uji statistik, yaitu uji t.Dari data penelitian, diperoleh hasil uji t yang disajikan pada Tabel 7.

Tabel 7. Uji perbedaan rerata data peningkatan self-Efficacy (SE) mahasiswa

\begin{tabular}{|c|c|c|c|c|}
\hline Kelompok KAM & Pembelajaran & $T$ & Sig & $\mathbf{H}_{\mathbf{0}}$ \\
\hline \multirow{2}{*}{ Keseluruhan } & PBL & \multirow{2}{*}{$-3,83$} & \multirow{2}{*}{0,000} & \multirow{2}{*}{ Ditolak } \\
\hline & $\mathrm{PK}$ & & & \\
\hline \multirow{2}{*}{ Tinggi } & PBL & \multirow{2}{*}{$-1,21$} & \multirow{2}{*}{0,251} & \multirow{2}{*}{ Diterima } \\
\hline & $\mathrm{PK}$ & & & \\
\hline \multirow{2}{*}{ Sedang } & PBL & \multirow{2}{*}{$-2,84$} & \multirow{2}{*}{0,008} & \multirow{2}{*}{ Ditolak } \\
\hline & PK & & & \\
\hline \multirow{2}{*}{ Rendah } & PBL & \multirow{2}{*}{$-2,97$} & \multirow{2}{*}{0,010} & \multirow{2}{*}{ Ditolak } \\
\hline & PK & & & \\
\hline
\end{tabular}

Berdasarkan tabel 7 diperoleh bahwa secara keseluruhan mahasiswa yang mendapatkan pembelajaran PBL memperoleh peningkatan self-efficacy lebih baik daripada mahasiswa yang mendapat pembelajaran konvensional. Begitu juga ditinjau dari KAM rendah dan 
sedang, mahasiswa yang mendapatkan pembelajaran PBL memperoleh peningkatan selfefficacy lebih baik daripada mahasiswa yang mendapat pembelajaran konvensional. Namun untuk KAM tinggi mahasiswa yang mendapatkan pembelajaran PBL memperoleh peningkatan self-efficacy tidak lebih baik daripada mahasiswa yang mendapat pembelajaran konvensional.

Untuk peningkatan self efficacy (SE) mahasiswa per aspek self efficacy (SE) disajikan dalam Tabel 8.

Tabel 8. Data peningkatan self efficacy (SE) mahasiswa per aspek

\begin{tabular}{clccc}
\hline \multirow{2}{*}{$\begin{array}{c}\text { Aspek } \\
\text { ke- }\end{array}$} & \multirow{2}{*}{$\begin{array}{c}\text { Aspek self } \\
\text { efficacy (SE) }\end{array}$} & Pembelajaran & \multicolumn{2}{c}{ Rata-rata } \\
\cline { 3 - 5 } \multirow{2}{*}{1} & Pengalaman & Pretes & Postes \\
\cline { 3 - 5 } & otentik & PBL & 1,960 & 2,390 \\
\cline { 3 - 5 } 2 & Pengalaman & PK & 2,120 & 2,400 \\
\cline { 3 - 5 } & orang lain & PBL & 2,578 & 2,750 \\
\cline { 3 - 5 } 3 & Sosial/verbal & PK & 2,490 & 2,630 \\
\cline { 3 - 5 } & & PBL & 1,640 & 2,027 \\
\cline { 3 - 5 } 4 & Psikologis & PK & 1,794 & 1,931 \\
\cline { 3 - 5 } & & PBL & 2,020 & 2,411 \\
\hline
\end{tabular}

Pada tabel 8 terlihat bahwa aspek self efficacy (SE) terbesar yaitu aspek pengalaman orang lain (baik pada kelas PBL maupun kelas PK), sedangkan aspek self efficacy (SE) terkecil yaitu aspek sosial/verbal (baik pada kelas PBL maupun kelas PK).

\section{Pembahasan}

Hasil penelitian ini menunjukkan bahwa secara keseluruhan peningkatan self-efficacy mahasiswa pada mata kuliah program linier yang mendapat PBL lebih baik daripada mahasiswa yang mendapat pembelajaran konvensional. Hasil penelitian ini sejalan dengan penelitian Arnawa (2010), Kurniawan (2012), Aryati (2012) dan Yanti (2016) yang menyatakan bahwa model pembelajaran berbasis masalah dapat meningkatkan self-efficacy siswa secara signifikan dibandingkan dengan pembelajaran konvensional.

Dalam pembelajaran PBL mahasiswa dibantu untuk mengembangkan kemampuan berpikir, pemecahan masalah, dan keterampilan intelektual, belajar peran melalui pelibatan dalam pengalaman nyata atau simulasi, dan menjadi pelajar yang otonom dan mandiri. Hal ini terlihat dari tahapan-tahapan dalam PBL yang terdiri dari empat tahap, yaitu tahap orientasi masalah, tahap mengorganisasikan mahasiswa, tahap menyelidiki secara mandiri atau berkelompok, tahap mengembangkan dan mempresentasikan hasil kerja, serta tahap analisis dan mengevaluasi proses (Sugiyanto: 2010). 
Pada tahap orientasi masalah mahasiswa dihadapkan pada suatu permasalahan autentik dan bermakna yang dapat memberikan kemudahan untuk melaksanakan penyelidikan dan inkuiri, mengajukan pertanyaan dan dialog, yang terpenting pada tahap ini bahwa pendidik melakukan scaffolding, yaitu membantu mahasiswa untuk mencapai tingkat pemahaman yang lebih tinggi. Pada tahap mengorganisasikan mahasiswa meneliti, mahasiswa diberikan kesempatan untuk mengembangkan self-efficacy yang dimiliki. Pada tahap ini, sumber selfefficacy yang ditekankan pada aspek pengalaman otentik, pengalaman orang lain, dan pendekatan sosial.

Pada tahap menyelidiki secara mandiri atau berkelompok, mahasiswa dilatih untuk memahami, mengklarifikasi, memilih strategi penyelesaian, serta menyelesaikan masalah yang diberikan secara mandiri atau berkelompok, kemampuan membuat rencana berdasarkan aspek pengalaman otentik, pengalaman orang lain, pendekatan sosial, dan psikologis yang ditekankan. Pada tahap ini ada kelompok mahasiswa yang pasif, hal ini disebabkan di dalam kelompok tersebut mahasiswa kurang mengerti dan malu bertanya, sehingga kesulitan untuk menyelesaikan permasalahan.

Pada tahap mengembangkan dan mempresentasikan hasil kerja, mahasiswa dilatih dan dibiasakan untuk dapat mengumpulkan data, berani mempresentasikan jawaban yang diperoleh di depan kelas, serta membandingkan jawaban dengan kelompok lain, kemampuan membuat rencana pemecahan dan melakukan perhitungan berdasarkan aspek pendekatan sosial, dan psikologis yang ditekankan. Pada tahap ini mahasiswa mulai membiasakan diri untuk berani tampil mempresentasikan hasil kerja. Pada tahap menganalisis dan evaluasi, mahasiswa dilatih untuk memeriksa kembali jawaban dan dapat menarik kesimpulan dari setiap pembelajaran, kemampuan memeriksa kembali hasil berdasarkan aspek pengalaman otentik, pengalaman orang lain, dan psikologis yang ditekankan. Pada tahap ini mahasiswa yang sudah memiliki jawaban yang benar akan lebih percaya diri dengan jawabannya, sedangkan mahasiswa yang jawabannya salah akan memeriksa kembali jawaban mereka, sehingga mahasiswa akan lebih teliti lagi dalam melakukan perhitungan.

Pada pertemuan pertama, kebanyakan mahasiswa masih kesulitan untuk mengikuti pembelajaran, mahasiswa masih terbiasa dengan pembelajaran konvensional. Selama pembelajaran berlangsung, mahasiswa diajak untuk terlibat aktif dalam pembelajaran, dengan cara peneliti menanyakan kesulitan apa yang dihadapi mahasiswa, melihat sampai dimana kemampuan mahasiswa dalam mengerjakan LKM yang diberikan, dan memberikan dorongan agar mahasiswa percaya diri untuk menampilkan jawaban dari kelompok mereka, untuk diperiksa secara bersama-sama. Untuk setiap kali pertemuan, terjadi peningkatan keaktifan 
dalam proses pembelajaran, mahasiswa semakin antusias menyelesaikan LKM yang diberikan, mahasiswa tidak malu untuk bertanya ketika menghadapi persoalan yang kurang mereka pahami, dan mahasiswa mulai berani untuk tampil mempresentasikan hasil jawaban serta terlibat aktif dalam proses menganalisis dan mengevaluasi baik dalam kelompok maupun dalam diskusi kelas. Hal ini sejalan dengan pendapat Rusman (2013) yang menyatakan bahwa PBL merupakan inovasi dalam pembelajaran karena dalam PBL, kemampuan berpikir peserta didik betul-betuk dioptimalisasikan melalui proses kerja kelompok atau tim yang sistematis, sehingga siswa dapat memberdayakan, mengasah, menguji, dan mengembangkan kemampuan berpikirnya secara berkesinambungan.

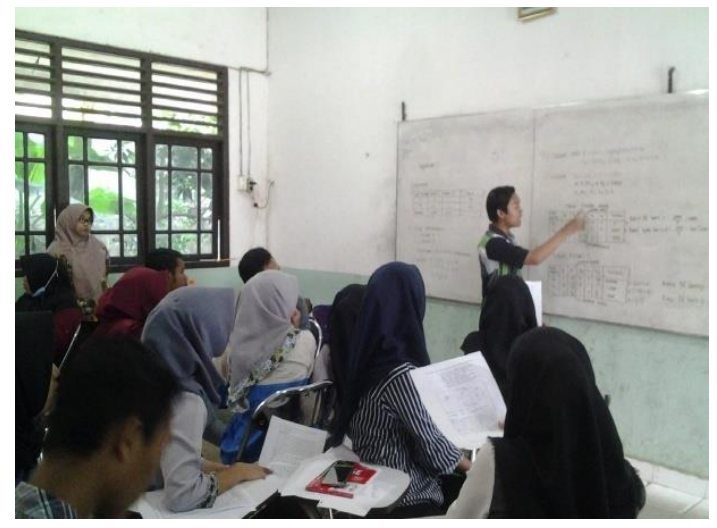

Gambar 1. Mahasiswa sedang mempresentasikan hasil kerja

Berdasarkan Gambar 1 memperlihatkan bahwa salah seorang mahasiswa mempresentasikan hasil kerja kelompoknya di depan kelas. Tampilan mahasiswa ini merupakan wujud dari rasa percaya diri dalam menyampaikan hasil kerja kelompok di hadapan mahasiswa lain dan memiliki kemampuan berkomunikasi secara efektif. Hal ini dapat menumbuhkan self-efficacy mahasiswa dalam pembelajaran program linier, ini merupakan salah satu ciri mahasiswa yang memiliki rasa percaya diri, kerja keras, berani tampil dalam menguraikan gagasannya, kreatif dan kritis dalam berbagai pemecahan masalah yang dihadapi, dan tidak mudah menyerah. Hal ini sejalan dengan teori Bandura (1977) yang menyatakan seseorang yang memiliki self-efficacy yang kuat dalam kompetensi akan mempertahankan usahanya walaupun mengalami kesulitan, sedangkan seseorang dengan self-efficacy lemah mudah dikalahkan oleh pengalaman yang sulit.

Indikator self-efficacy terbesar terdapat pada aspek pengalaman orang lain, artinya mahasiswa banyak belajar menerima dari luar dirinya atau orang lain yang memungkinkan mereka untuk mengamati dan meniru perilaku serta mengadopsi ke dalam pola perilaku mereka sendiri. pemodelan menjadi bagian paling penting dalam perkembangan self-efficacy 
mahasiswa. Sedangkan indikator self-efficacy terkecil terdapat pada aspek sosial/verbal, artinya pengakuan sosial atas kerja keras dalam mencapai prestasi tidak memberikan pengaruh yang signifikan terhadap self-efficacy mahasiswa dibandingkan dengan aspek lain.

\section{SIMPULAN}

Berdasarkan hasil dan pembahasan pada penelitian ini, maka dapat disimpulkan bahwa peningkatan self-efficacy mahasiswa pada mata kuliah program linier yang mendapat PBL lebih baik daripada mahasiswa yang mendapat pembelajaran konvensional ditinjau dari keseluruhan maupun KAM (sedang, rendah) meskipun dengan nilai gain berada pada kategori rendah, sedangkan untuk KAM tinggi berada pada kategori sedang.

\section{UCAPAN TERIMA KASIH}

Peneliti menyampaikan ucapan terima kasih kepada Mentri Riset, Teknologi dan Pendidikan Tinggi yang telah memberikan sponsor penelitian ini melalui skema Penelitian Dosen Pemula untuk tahun anggaran 2017.

\section{DAFTAR PUSTAKA}

Arnawa, I N. (2010). Pengaruh Model Self-Regulated Learning Terhadap Self Efficacy Siswa SMP Ditinjau Berdasarkan Gender. Tesis tidak dipublikasikan, Program Pascasarjana Undiksha Singaraja.

Aryati, K N. (2012). Pengaruh Model Pembelajaran Berbasis Masalah (PBL) dalam Pembelajaran Fisika Terhadap Keterampilan Berpikir Kritis dan Self Efficacy Siswa SMA. Tesis tidak dipublikasikan, Program Pascasarjana Undiksha Singaraja.

Bandura, A. (1994). Self-Efficacy. In V.S. Ramachaudran (Ed.), Encyclopedia of human behaviour (Vol 4, pp. 71-81). New York: Academic Press (Online), (http://www.uky.edu/ eushe2/Bandura/Bandura1994EHB.Pdf.), diakses tanggal 8 Maret 2016.

Bandura, A. (1997). Self-Efficacy: The Exercise of Control. New York: W.H. Freeman and Company.

Creswell. (2009). Research Design Pendekatan Kualitatif, Kuantitatif, dan Mixed Edisi Ketiga. Yogyakarta: Pustaka Pelajar.

Dasna, I W. \& Sutrisno (2007). Pembelajaran Berbasis Masalah (Online), (http://lubisgrafura.wordpress.com/2007/09/19/pembelajaran-berbasis masalah/), diakses tanggal 8 Maret 2016.

Islahul, N \& Utiya, A. (2015). Implementasi Model Pembelajaran Berbasis Masalah (PBM) Untuk Melatihkan Keterampilan Berpikir Kritis dan Self Efficacy Pada Materi Pokok Faktor-Faktor Yang Mempengaruhi Laju Reaksi Kelas XI SMA Negeri 4 Sidoarjo. UNESA Journal of Chemical Education, 4 (1): 62-68.

Kartono, dkk. (2007). Evaluasi Kualitas Materi Metode Simpleks Pada Bahan Ajar Program Linier. Jakarta : Universitas Terbuka. 
Kholidi, M \& Saragih, S. (2011). Peningkatan Kemampuan Koneksi dan Pemecahan Masalah Matematika Siswa SMA Melalui Pembelajaran Kooperatif. Jurnal Pendidikan Matematika Paradikma, 5 (2): 166-185.

Kurniawan, B. W. (2012). Penerapan Model Modified Problem Based Learning (PBL) Untuk Meningkatkan Kemampuan Berpikir Kritis dan Efikasi Diri Mahasiswa. Tesis (Online), (http://karya-ilmiah.um.ac.id/index.php/disertasi/article/view/22980), diakses tanggal 23 Juli 2016.

Mahardikawati, D. (2011). Hubungan antara Self-efficacy dengan Prestasi Belajar Siswa (Studi Deskriptif pada Siswa Kelas VIII SMP Negeri 2 Sukaraja Kabupaten Sukabumi tahun Ajaran 2011-2012). Skripsi tidak dipublikasikan, Bandung, Psikologi FIP UPI.

Rohana, \& Lestarianingsih, Y. (2016). Model Pembelajaran Reflektif untuk Meningkatkan Kemampuan Pemecahan Masalah dan Komunikasi Matematis Mahasiswa Calon Guru. Hibah Penelitian Direktorat Riset dan Pengabdian Masyarakat Direktorat Jenderal Penguatan Riset dan Pengembangan Kementrian Riset,Teknologi dan Pendidikan Tinggi. Tidak diterbitkan, Palembang, Universitas PGRI Palembang.

Rusman. (2013). Model-Model Pembelajaran. Jakarta: PT. Rajagrafindo Persada.

Sanjaya, W. (2011). Strategi Pembelajaran berorientasi Standar Proses Pendidikan. Jakarta: Kencana Prenada Media Group.

Somakim. (2010). Peningkatan Kemampuan Berpikir Kritis dan Self-Efficacy Matematik Siswa Sekolah Menengah Pertama dengan Penggunaan Pendekatan Matematika Realistik. Disertasi tidak diterbitkan, Bandung, PPS UPI.

Sugiyanto. (2010). Model-Model Pembelajaran Inovatif. Surakarta: Yuma Pustaka.

Sulthon. (2014). Membangun Efikasi Diri untuk Meningkatkan Performansi Siswa di Sekolah. Jurnal Elementary, 2(2): 251-267.

Tarmizi and Bayat. (2012). Collaborative Problem-Based Learning in Mathematics:A cognitive load Perspective. Procedia-Social and Behavioral Science, 32: 344 - 350.

Yanti, A.A. (2016). Penerapan Model Pembelajaran Problem Based Learning untuk Meningkatkan Kemampuan Pemecahan Masalah dan Komunikasi Matematis Serta Self $\begin{array}{llll}\text { Efficacy Siswa SMP. } & \text { (Online), }\end{array}$ (https://www.google.com/url?sa=t\&rct=j\&q=\&esrc=s\&source=web\&cd=1\&cad=rja\&u act $=8 \& v e d=0$ ahUKEwjRi4W52bDXAhWHN48KHdFPBpIQFggpMAA\&url=http $\% 3 \mathrm{~A}$ \%2F\%2Frepository.unpas.ac.id\%2F12544\%2F1\%2FARTIKEL\%2520\%2528\%2520A TI\%2520ADI\%2520YANTI\%2520\%2520148060036\%2520\%2529\%2520\%25281\%2529.docx\&usg=AOvVaw0H6ioBZK 0MyeHFR1S2ZkB0.), diakses tanggal 8 Maret 2016. 